\author{
Dr. sc. Dražen Škrtić \\ PU karlovačka, Služba kriminalističke policije
}

\title{
PRIJENOS RAČUNALNIH PODATAKA - POKRETNA STVAR U KAZNENOM ZAKONU
}

\author{
UDK: 343. (497. 5) \\ Pregledni rad \\ Primljeno: 1.02. 2016.
}

\begin{abstract}
Kaznenopravna reakcija na razvoj informacijske i komunikacijske tehnologije i zlouporabe javne komunikacijske usluge već dugi vremenski period ne slijedi suvremene modele naplate digitalnih elektroničkih komunikacijskih usluga, usluga s dodanom vrijednosti, prijenosa govora, zvuka, slike, teksta i računalnih podataka u jedinicama prilagođenima vrsti usluge. Zakonodavac nije slijedio trendove progresivnog razvoja informacijske i komunikacijske tehnologije, niti je prilagodio definiciju pokretne stvari. Prijenos govora, zvuka, slike, teksta i računalnih podatka na daljinu, prema odredbama Kaznenog zakona, nije pokretna stvar, niti se ekstenzivnom interpretacijom pojma telefonski impuls može podvesti pod definiciju pokretne stvari. Neovlašteno korištenje suvremenih oblika komunikacije i prijenosa podataka ne može se podvesti pod kazneno djelo krađe i teške krađe jer bi to bilo u suprotnosti s načelom zakonitosti. Sudske odluke u postupcima pokrenutima zbog neovlaštenog korištenja usluga s dodanom vrijednosti i prijenosom računalnih podataka ni ne definiraju navedene usluge kao pokretne stvari. Temeljem općih naznaka suvremenih komunikacijskih usluga, poredbenih propisa i sudske prakse proizlazi nužnost da se u Kaznenom zakonu prijenos slike, zvuka, teksta i računalnih podataka na daljinu definira kao pokretna stvar.
\end{abstract}

\section{Ključne riječi: kazneni zakon, telefonski impulsi, pokretna stvar, prijenos računalnih podataka}

\section{UVOD}

Kazneno pravo kroz povijesni razvoj kontinuirano inkriminira protupravno prisvajanje tuđe pokretne stvari. U zakonskom opisu kaznenog djela krađe i teške krađe, pokretna stvar je bitni element kaznenog djela. Pokretna stvar definirana je odredbama Zakona o vlasništvu i drugim stvarnim pravima.

Prema odredbama članka 2. Zakona o vlasništvu i drugim stvarnim pravima, ${ }^{1}$ predmet prava vlasništva i drugih stvarnih prava može biti svaka pokretna (pokretnina) ili nepokretna stvar (nekretnina), osim onih koje nisu za to sposobne.

1 Zakon o vlasništvu i drugim stvarnim pravima, NN 91/96, 68/98 - Zakon o izmjenama i dopunama Zakona o prodaji stanova na kojima postoji stanarsko pravo, 137/99-Odluka USRH, 22/00-Odluka USRH, 73/00, 129/00 - Zakona o izmjenama i dopunama Stečajnog zakona, 114/01, 79/06, 141/06, 146/08, 38/09, 153/09, 143/12 i 152/14. 
Stvari su materijalni dijelovi prirode, različiti od ljudi, koji služe ljudima za uporabu. Uzima se da su stvari i sve drugo što je zakonom s njima izjednačeno. Pokretnine su stvari koje se mogu premjestiti s jednoga mjesta na drugo, a da im se ne naruši bit (supstanca). Stvari koje su po svojoj naravi pokretne smatraju se u pravnom smislu nepokretnima ako su pripadak nepokretne stvari ili ih zakon izjednačuje s nekretninama. Zakonom neka vrsta prava ili bilo što drugo može biti izjednačeno s pokretnim stvarima.

Tehnološki razvoj nametnuo je potrebu zakonske definicije pokretne stvari i inkriminaciju neovlaštenog korištenja akumulirane energije. Inkriminacija neovlaštenog korištenja akumulirane energije i prijenosa govora i zvuka na daljinu kao protupravnog prisvajanja tuđe pokretne stvari postala je nužna kad je njihovo neovlašteno korištenje postalo smetnja ostvarivanju pojedinačnih, grupnih i općih interesa društva u zaštiti imovine.

Odredbama kaznenog zakona, relativno rano, akumulirana energija proizvedena i sakupljena energija za davanje svjetlosti, topline ili kretanje u odredbama Krivičnog zakona ${ }^{2}$ odnosno električna energija ${ }^{3}$ definirana je kao pokretna stvar. Proizvedenu ili sakupljenu energiju moguće je izmjeriti i s manjom ili većom vjerojatnosti utvrditi koju je količinu energije počinitelj neovlašteno iskoristio i kolika je vrijednost te energije. Dakle, vlasništvu bez konstantnih tjelesnih obilježja, izričitom zakonskom odredbom daje status pokretne stvari.

Predmet neovlaštenog korištenja postaju i usluge prijenosa govora na daljinu. Neovlašteno korištenje govornih usluga i zlouporaba telekomunikacijskih sustava nametali su potrebu kaznenopravne zaštite telekomunikacijskih usluga. U nedostatku zakonske definicije telefonskih impulsa kao pokretne stvari, sudovi su zbog potrebe kažnjavanja neovlaštenog korištenja telefonskih usluga, ekstenzivnim tumačenjem pojma pokretne stvari, pojam pokretne stvari proširili i na telefonske impulse. Međutim, stajalište suda prema kojem su telefonski impulsi pokretna stvar jer je mjerna količina impuls koji ima određenu tržišnu vrijednost i može biti predmet oduzimanja, a time i stjecanja protupravne imovinske koristi, nije općeprihvaćeno. ${ }^{4}$ VSRH smatra da krađa telefonskih impulsa zaslužuje da bude predviđena kao

2 Članak 3., stavak 9. Krivičnog zakona Socijalističke Republike Hrvatske NN 25/77 od 25. lipnja 1977. godine.

3 Prema Rješenju VSRH broj: IV Kž-11/1992-3. od 10. lipnja 1992. godine u članku 3., točka 9. $\mathrm{KZH}-\mathrm{a}$ dana je ekstenzivna definicija pokretne stvari, pa se kao pokretna stvar smatra i svaka proizvedena ili sakupljena energija za davanje svjetlosti, topline i kretanja. Ta se definicija odnosi samo na električnu struju.

4 Kako je opće poznato, telefon radi na principu pretvaranja električne energije u zvučnu, i obrnuto, električna energija koristi se za prijenos (kretanje) govora, a mjerna količina je impuls koji ima određenu tržišnu vrijednost. Prema tome, u ovom slučaju ispunjeni su uvjeti definicije pokretne stvari, koja može biti predmet oduzimanja, a time i stjecanja protupravne imovinske koristi. Iz odluke Okružnog suda u Zagrebu, KŽ-1670/86 od 1. srpnja 1986. 
imovinski delikt, ali tako dugo dok to zakonodavac ne učini izričitim propisom, podvođenje krađe impulsa pod krađu predstavljalo bi zabranjenu analogiju i stoga kršenje načela zakonitosti. ${ }^{5}$ Isto stajalište proizlazi i iz Rješenja VSRH-a, prema kojem se pokretnom stvari smatra samo električna struja, a ne i telefonski impulsi. ${ }^{6}$

Telefonski impulsi nemaju svojstva koja ima sakupljena ili proizvedena energija, niti svojstva pokretne stvari prema zakonu, stoga su izričitom odredbom Kaznenog zakona $^{7}$ i telefonski impulsi definirani kao pokretne stvari. I prema odredbama novog Kaznenog zakona pokretna je stvar i svaka proizvedena ili skupljena energija za davanje svjetlosti, topline ili kretanja, kao i telefonski impulsi. ${ }^{8}$

Razvoj suvremenih informacijskih i komunikacijskih tehnologija i usluga, učinio je obračun i naplatu komunikacijskih usluga prema telefonskim impulsima neprimjenjivom. Usluge prijenosa kratke tekstualne poruke (SMS), prijenosa slike, govora i zvuka porukom (MMS), javno dostupne elektroničke komunikacijske usluge i usluge s posebnom tarifom nije moguće obračunati i naplatiti sustavom obračuna i naplate telefonskih impulsa. Razvijeni su novi tarifni modeli koje nije moguće jednostavno definirati kroz vremensko trajanje impulsa i njegovu cijenu. Usluge u telekomunikacijskoj mreži, koje nisu javne govorne usluge, obračunavaju se i naplaćuju u jedinicama koje su prilagođene za tu vrstu usluge. Razvoj informacijske i komunikacijske tehnologije definiranje telefonskih impulsa kao pokretne stvari učinio je zastarjelim i nepotrebnim, ali i doveo do potrebe definiranja komunikacijskih usluga i prijenosa računalnih podataka, bez obzira na to prenose li se kao pokretne stvari govor, zvuk, slika ili računalni podaci.

Nedostatak definicije prijenosa govora, zvuka, slike i prometa računalnih podataka kao pokretne stvari u sudskoj praksi rezultira potpunim izbjegavanjem definiranja prometa računalnih podataka kao pokretne stvari odnosno bitnog elementa kaznenog djela.

$\mathrm{U}$ radu, autor deskriptivnom metodom analizira specifičnosti suvremenih usluga govornih komunikacija i prijenosa računalnih podataka, način naplate tih

5 Nema sumnje da krađa telefonskih impulsa zaslužuje da bude predviđena kao imovinski delikt, ali tako dugo dok to zakonodavac ne učini izričitim propisom, podvođenje krađe impulsa pod krivično djelo krađe iz čl. 130., st. 1. KZH-a predstavljalo bi zabranjenu analogiju i stoga kršenje načela zakonitosti. Iz Rješenja VSRH broj: IV Kž-11/1992-3. od 10. lipnja 1992. godine.

6 Ovo stoga što to kazneno djelo čini onaj tko oduzme tuđu pokretnu stvar, a u ovom slučaju nedostaje upravo taj bitan elemenat kaznenog djela krađe - oduzimanje tuđe pokretne stvari jer se osumnjičenici stavlja na teret krađa telefonskih impulsa, koji, u vrijeme navodne krađe, nisu predstavljali pokretnu stvar s obzirom na odredbu čl. 3., st. 9. KZRH-a (koja se primjenjuje na osumnjičenicu, sukladno odredbi čl. 3., st. 1. KZ/97) iz koje proizlazi da se pokretnom stvari smatrala samo električna struja, a ne i telefonski impulsi. Rješenje VSRH broj: IV Kž-35/1999-2 od 1. lipnja 1999. godine.

7 Članak 89., stavak 27. Kaznenog zakona, NN 110/97, 27/98, 50/00, 129/00, 51/01, 111/03, 190/03, 105/04 i 71/06, 110/07, 152/08, 57/11 i 77/11, dalje KZ/97.

8 Članak 87., stavak 16. Kaznenog zakona, NN 125/11, 144/12, 56/15 i 61/15 - Ispravak, dalje $\mathrm{KZ} / \mathbf{1 1}$. 
Dr. sc. Dražen Škrtić: Prijenos računalnih podataka - pokretna stvar u kaznenom zakonu Zbornik radova Pravnog fakulteta u Splitu, god. 53, 3/2016., str. 855.-872.

usluga, komparira zakonska rešenja u poredbenim propisima i predlaže promjene u definiranju pojma pokretna stvar u kaznenom zakonu.

\section{OBRAČUN TELEKOMUNIKACIJSKIH USLUGA}

Informacijska i komunikacijska tehnologija posljednjih se godina progresivno razvija. Suvremeni mobilni telefoni, pametni telefoni (smart phone), osim za komunikaciju i prijenos podataka, koriste se i za plaćanje. ${ }^{9} \mathrm{U}$ prikazu uporabe suvremene informacijske i komunikacijske tehnologije ograničit ćemo se samo na komunikacije, prijenos govora, slike, zvuka i podataka na daljinu. Radi sagledavanja razvoja komunikacijske tehnologije i načina obračuna javnih komunikacijskih usluga, donosimo sumarni pregled razvoja obračuna i naplate komunikacijskih usluga.

\subsection{Telefonski impulsi}

Prema odredbama Pravilnika o općimuvjetima za obavljanje telekomunikacijskih usluga, obračunski elementi tarifnog sustava telefonskog prometa na temelju kojih korisnici plaćaju ostvarene usluge zasnivaju se na cijeni svih vrsta telefonskih razgovora, utvrđuju se na bazi cijene impulsa, a u međunarodnom prometu na bazi cijene jedne minute trajanja razgovora, registriranje podataka za naplatu obavljenih razgovora obavlja se tarifnim impulsima, a trajanje impulsnih intervala po zonama određuje se za unutrašnji promet - tarifnim sustavom telefonskog prometa, a za međunarodni promet - iz cijene minute razgovora određene međunarodnim protokolima i utvrđene cijene impulsa u unutrašnjem prometu. ${ }^{10}$ Cijena impulsa određivana je Odlukom Vlade RH o suglasnosti na povećanje cijene telefonskog impulsa i cijene pisama i dopisnica i objavljivana u službenom glasilu. ${ }^{11}$

9 Plaćanje parkinga SMS-porukom, plaćanje računa SMS-porukom, prijenos novca SMS-porukom (između tekućih računa Raiffeisenbank te MasterCard i Visa kartica izdanih od bilo koje banke i između dva računa istog davatelja usluga, obnova pretplatničkog računa SMS-porukom, plaćanje javnog prijevoza SMS-porukom, navigacija.

10 Članak 50. Pravilnika o općim uvjetima za obavljanje telekomunikacijskih usluga, NN 84/95.

11 Vlada Republike Hrvatske suglasna je s povećanjem cijene telefonskog impulsa u unutarnjem prometu sa 1,30 na 2 hrvatska dinara. NN 23/92., Vlada Republike Hrvatske suglasna je s povećanjem cijene telefonskog impulsa u unutarnjem prometu sa 10 na 15 hrvatskih dinara, uz trajanje impulsnog intervala prema važećem tarifnom sustavu NN 8/93., Vlada Republike Hrvatske suglasna je s povećanjem cijene telefonskog impulsa u unutarnjem prometu sa 15 na 20 hrvatskih dinara, uz trajanje impulsnog intervala prema važećem tarifnom sustavu, NN 16/93., Vlada Republike Hrvatske suglasna je s povećanjem cijene telefonskog impulsa u unutarnjem prometu, sa 20 na $28 \mathrm{HRD}$, uz trajanje impulsnog intervala prema važećem tarifnom sustavu, NN 33/93. 
Razvoj komunikacijske mreže osamdesetih godina prošlog stoljeća i povećanje dostupnosti telefonskih usluga neminovno su doveli do zlouporaba koje su postale ozbiljna smetnja naplati uporabe telefonske komunikacije. Definicija telefonskog impulsa kao pokretne stvari uvedena je u kazneno zakonodavstvo Kaznenim zakonom koji je stupio na snagu 01. siječnja 1998. godine, odredbom prema kojoj je pokretna stvar i svaka proizvedena ili skupljena energija za davanje svjetlosti, topline ili kretanja, kao i telefonski impulsi, ${ }^{12}$ ostala nepromijenjena i u odredbama novog Kaznenog zakona. ${ }^{13}$

\subsection{Telekomunikacijski promet}

Prema odredbama Pravilnika o telekomunikacijskim uslugama, cijena ostvarenog telekomunikacijskog prometa u nepokretnoj mreži utvrđuje se na temelju vrste telekomunikacijskog prometa, vrste telekomunikacijske usluge, vrste telekomunikacijske mreže, zone zemlje s kojom je veza uspostavljena, te vremena u kojem je veza ostvarena. Trajanje telekomunikacijske veze izražava se u minutama i sekundama, a cijena je izražena po minuti, ostvareni telekomunikacijski promet obračunava se i naplaćuje primjenom obračunskih jedinica, izdavanjem računa. ${ }^{14}$ Prema Zakonu o izmjenama i dopunama zakona o elektroničkim komunikacijama, javno dostupna telefonska usluga, uporaba javne telefonske govornice naplaćuje se umanjenjem iznosa na unaprijed plaćenim karticama kapaciteta određenog broja impulsa (prepaid kartice) ${ }^{15}$ koje su definirane kao znakovi za vrijednost, ${ }^{16}$ uključujući i kartice za uporabu s pozivnim kodovima, naplatom kovanicama ili kreditnim/debitnim karticama, a obračun ostvarenog telekomunikacijskog prometa započinje u trenutku javljanja pozvanog pretplatnika. ${ }^{17}$ Krivotvorenje telefonskih

12 Članak 89., stavak 27. KZ/97.

13 Članak 87., stavak 16. KZ/11.

14 Članak 32. Pravilnika o telekomunikacijskim uslugama, NN 183/04.

15 Članak 2., stavak 1., točka 21. i točka 22. Zakona o izmjenama i dopunama zakona o elektroničkim komunikacijama, NN 90/11.

16 Pritom je važno reći da osnovnim zakonskim propisom koji regulira ovu materiju, Zakonom o pošti, oba znaka, i to poštanska marka kao poštanski vrijednosni znak te telefonska kartica kao telekomunikacijski vrijednosni znak, imaju pravno svojstvo vrijednosnih znakova kao surogata za plaćanje gotovim novcem, jednako kao i Pravilnikom o poštanskim markama i ostalim vrijednosnicama u koje ulazi i telefonska kartica. Međutim, po sudu prvog stupnja napravljena je značajna pravna razlika između poštanske marke, koja i dalje ima pravno svojstvo vrijednosnog znaka, i telefonske kartice koja bi, prema stajalištu tog suda, sada bila privatna isprava, a izdane se od istog izdavača, što bi stvorilo daljnju pravnu nesigurnost u platnom prometu i poslovanju vrijednosnim znakovima. Presuda i Rješenje Vrhovnog suda Republike Hrvatske broj: I Kž 968/03-6 od 30. kolovoza 2006. godine.

17 Znakovi za vrijednost su isprave izdane na temelju propisa i služe kao dokaz da je nešto plaćeno, a imaju pravno svojstvo vrijednosnih znakova kao surogata za plaćanje gotovim novcem. 
Dr. sc. Dražen Škrtić: Prijenos računalnih podataka - pokretna stvar u kaznenom zakonu Zbornik radova Pravnog fakulteta u Splitu, god. 53, 3/2016., str. 855.-872.

kartica, ${ }^{18}$ bez obzira na to radi li se o potpunoj krivotvorini ${ }^{19}$ ili samo o preinaci postojeće telefonske kartice, ${ }^{20}$ propisano je kao kazneno djelo odredbama članka 276. KZ/97 - Krivotvorenje znakova za vrijednost ${ }^{21}$ koji uz minimalnu lingvističku intervenciju, koja ne mijenja sadržaj ni smisao odredbe, ima kontinuitet u odredbama članka 276. KZ/11.22

18 Pod toč. 3) izreke pobijane presude opt. L. M. proglašen je krivim zbog kaznenog djela krivotvorenja privatne isprave iz čl. 311., st. 1. KZ-a, iako je bio optužen zbog kaznenog djela krivotvorenja znakova za vrijednost, i to telefonske kartice kao telekomunikacijskog vrijednosnog znaka. Državni odvjetnik, tijekom glavne rasprave, nije izmijenio činjenični opis optužbe u odnosu na to djelo, pa je optuženik osuđen za drugo djelo, što istovremeno ukazuje na to da je sud prvog stupnja preuzeo ulogu državnog odvjetnika u postupku izmjenom činjeničnog opisa djela, iako je on na temelju odredbe čl. 350., st. 1. ZKP-a, vezan za činjenični opis djela sadržan u optužnici. Osim toga, kazneno djelo krivotvorenja znakova za vrijednost iz čl. 276., st. 1. KZ-a, ima zaštitni objekt sigurnost platnog prometa i poslovanja i ulazi u Glavu XXI. Kaznenog zakona, a odnosi se na kaznena djela protiv sigurnosti platnog prometa i poslovanja, dok kazneno djelo krivotvorenja privatne isprave ulazi u kaznena djela protiv vjerodostojnosti isprava (Glava XXIII. Kaznenog zakona), kojima su objekti zaštite čistoća, vjerodostojnost i nepovredivost isprava, iz čega je očito da postoji bitna razlika između navedenih kaznenih djela glede njihovih objekata zaštite, zakonskih obilježja, kao i visine zapriječenih kazni zatvora za odnosna djela. Pritom, iako državni odvjetnik nije na glavnoj raspravi izmijenio ni proširio optužnicu, prvostupanjski sud se upustio u izmjenu činjeničnog opisa djela na način da je upravo u činjeničnom opisu djela označio, bitno različito od državnog odvjetnika, da je modificirana telefonska kartica izrađena protivno Pravilniku o poštanskim markama i vrijednosnicama, koje izdaje HPT, te suprotna čl. 10. Svjetske poštanske konvencije i čl. 30 ., st. 2. Zakona o pošti, s naznakom vremena kada je od optuženika navedena telefonska kartica oduzeta. Na opisani način sud prvog stupnja je intervenirao u činjenični opis djela, dodajući one činjenice za koje je smatrao da čine obilježja kaznenog djela krivotvorenja privatne isprave, s obzirom na izdavača, te je optuženika proglasio krivim za kazneno djelo iz čl. 311., st. 1. KZ-a. Presuda i Rješenja VSRH broj: I Kž 968/03-6 od 30. kolovoza 2006. godine.

19 Tijekom postupka, provedenim vještačenjem, gdje nalaz vještaka optuženi niti ne osporava, nedvojbeno je utvrđeno da je telefonska kartica, koja je od opt. Š.Ooduzeta, krivotvorina. Optuženi Š. po svom obrazovanju tehničara za telekomunikacije, koji je radio u to vrijeme u TKC Z., posve sigurno je zna, da se radi o krivotvorenoj telefonskoj kartici, koja se trošenjem prazni i vrijednosti je 200 impulsa. Ona je nedvojbeno znak za vrijednost, a optuženi ju je pribaviosa jedinom namjerom da je uporabi kao pravu. Prema tome, u radnjama optuženoga stječu se svi bitni elementi objektivnog učina kaznenog djela iz čl. 276., st. 1. KZ-a. Presuda VSRH I Kž 682/01-8 od 30. siječnja 2002. godine.

20 Originalna telefonska kartica je preinačena pa se, nakon potrošenog broja telefonskih impulsa, automatski obnavlja na broj impulsa označen na samoj kartici. U Rješenju VSRH broj: II-4 Kr-280/00-3 od 31. kolovoza 2000. godine takva kartica naziva se „,beskonačna telefonska kartica“.

${ }^{21}$ Krivotvorenje znakova za vrijednost, Članak 276. KZ/97.

(1) Tko izradi lažne biljege ili poštanske marke ili druge znakove za vrijednost izdane na temelju propisa, ili tko preinači koji od tih pravih znakova s ciljem da ih uporabi kao prave ili da ih drugome dade na uporabu, ili tko takve lažne znakove uporabi kao prave ili ih s tim ciljem pribavi, kaznit će se kaznom zatvora od šest mjeseci do pet godina.

(2) Tko uklanjanjem žiga sa znaka za vrijednost ili na drugi način djeluje na već uporabljeni znak za vrijednost da bi mu dao izgled neuporabljenog znaka, ili tko već uporabljeni znak za vrijednost ponovno uporabi ili ga proda kao da nije uporabljen, kaznit će se novčanom kaznom ili kaznom zatvora do tri godine.

(3) Lažni znakovi za vrijednost oduzet će se.

22 Krivotvorenje znakova za vrijednost, Članak 276. KZ/11.

(1) Tko izradi lažne biljege, poštanske marke ili druge znakove za vrijednost izdane na temelju propisa ili ih preinači, pribavi ili dade drugome na uporabu s ciljem da ih uporabi kao prave, kaznit će se kaznom zatvora od šest mjeseci do pet godina.

(2) Tko uklanjanjem žiga sa znaka za vrijednost ili na drugi način djeluje na već uporabljeni znak za vrijednost da bi mu dao izgled neuporabljenog znaka ili tko već uporabljeni znak za vrijednost ponovno uporabi ili ga proda kao da nije uporabljen, kaznit će se kaznom zatvora do šest mjeseci. 
Prema odredbama Pravilnika o telekomunikacijskim uslugama, cijena ostvarenog telekomunikacijskog prometa u pokretnoj mreži izražava se po minuti, a naplaćuje se korisniku usluga prema ostvarenom telekomunikacijskom prometu u obračunskom razdoblju, uz primjenu obračunskih jedinica. ${ }^{23}$ Telekomunikacijski promet obračunava se prema stvarno ostvarenom prometu, obračunom telekomunikacijskog prometa i periodičnim ispostavljanjem računa ili se oduzima od iznosa unaprijed plaćenih usluga kroz telefonske kartice u nepokretnoj mreži ili bonove u pokretnoj mreži. ${ }^{24}$

Telekomunikacijski promet u pokretnoj mreži, pored prijenosa govora, uključuje uslugu kratke tekstualne poruke (SMS) te uslugu prijenosa slike, govora i zvuka porukom (MMS). Prema odredbama Pravilnika o telekomunikacijskim uslugama, cijene usluga u pokretnoj telekomunikacijskoj mreži, koje nisu javne govorne usluge, izražavaju se i naplaćuju u jedinicama prilagođenima za tu vrstu usluge. ${ }^{25}$

\subsection{Prijenos računalnih podataka}

Prema odredbama Kaznenog zakona, računani podatak je svako iskazivanje činjenica, informacija ili zamisli u obliku pogodnom za obradu u računalnom sustavu. ${ }^{26}$ Prijenos ili promet računalnih podataka ekvivalent je prijenosu govora, slike, zvuka i teksta na daljinu kroz javno dostupnu pokretnu i nepokretnu telekomunikacijsku mrežu.

Prijenos podataka uključuje i prijenos govora preko internetskog portala, ${ }^{27}$ koji ne obuhvaća javno dostupnu telefonsku uslugu, elektroničku poštu, ${ }^{28}$ prijenos teksta, prijenos slike i zvuka, ali i prijenos drugih računalnih podataka.

(3) Lažni znakovi za vrijednost će se oduzeti.

23 Članak 34., stavak 3. Pravilnika o telekomunikacijskim uslugama, NN 183/04.

24 Pokretna elektronička komunikacijska mreža: elektronička komunikacijska mreža koja omogućava uspostavljanje elektroničke komunikacijske veze i u uvjetima fizičkog kretanja korisnika usluga te mreže. Članak 3., stavak 1., podstavak 24. Pravilnika o načinu i uvjetima obavljanja djelatnosti elektroničkih komunikacijskih mreža i usluga, NN 154/11, 149/13, 71/14 i 24/15.

25 Članak 34., stavak 4. Pravilnika o telekomunikacijskim uslugama, NN 183/04.

26 Članak 87., stavak 19. KZ/11.

27 VoIP - prijenos glasa preko internetskog portala u nepokretnoj mreži, MoIP - prijenos glasa preko internetskog portala u pokretnoj mreži. Članak 2., stavak 18. Pravilnika o načinima i uvjetima obavljanja djelatnosti elektroničkih komunikacijskih mreža i usluga, NN 154/11, 149/13, 71/14 i 24/15.

28 Svaka tekstovna, glasovna, zvučna ili slikovna poruka odaslana javnom komunikacijskom mrežom, koja se može pohraniti u mreži ili terminalnoj opremi sve dok je primatelj ne preuzme. Cllanak 2., stavak 1., točka 11. Zakona o izmjenama i dopunama zakona o elektroničkim komunikacijama, NN 90/2011. 
Prijenos podataka, bez obzira na sadržaj, obračunava se i naplaćuje prema količini prenesenih podataka i brzini prijenosa računalnih podataka ${ }^{29}$ ili se naplaćuje neograničen prijenos računalnih podataka uz određenu brzinu prijenosa računalnih podataka. Brzina prijenosa računalnih podataka prilikom skidanja (download) računalnih podataka u pravilu je veća od brzine postavljanja računalnih podataka (upload).

Za prijenos podataka internetom između dislociranih korisnika razvijena je virtualna privatna mreža - VPN (Virtual Private Network) koja omogućava siguran i pouzdan prijenos podataka.

\subsection{Korisnički paketi}

Davatelji usluga sastavljaju i korisničke pakete koji uključuju korištenje fiksnog telefona, mobilnog telefona, fiksnog interneta, mobilnog interneta i TV-programa u kombinacijama koje najbolje odgovaraju korisniku. Paketi u pravilu sadrže određenu količinu svih ili samo pojedinih usluga iz korisničkog paketa koji su uključeni u mjesečnu naknadu kao što je količina prijenosa podataka u mobilnoj/ fiksnoj mreži, besplatne minute razgovora u mobilnoj/fiksnoj mreži, broj besplatnih SMS/MMS poruka ili broj TV-programa. Svako prekoračenje limita određene usluge posebno se naplaćuje prema unaprijed određenom cjeniku.

Određene usluge definirane su bez ograničenja, neograničen prijenos podataka „flat" ili neograničen broj SMS/MMS-poruka. Neovlašteno korištenje predstavlja štetu za davatelja usluga.

\subsection{Roaming}

Roaming je posebna vrsta usluge koja omogućuje dostupnost i izvan granica države u kojoj je registriran davatelj usluge (u zrakoplovima i brodovima). ${ }^{30}$ Roaming-uslugom obuhvaćene su sve javne komunikacijske usluge kao i prijenos podataka. Raoming-usluga je u pravilu znatno skuplja i naplaćuje su od oba korisnika komunikacije.

29 Cijene su u pravilu izražene za količine podataka od $100 \mathrm{MB}, 500 \mathrm{MB}, 1 \mathrm{~GB}$ itd. Brzina prijenosa izražava se brojem Mbit/s (12 Mbit/s, $20 \mathrm{Mbit} / \mathrm{s}, 32 \mathrm{Mbit} / \mathrm{s})$.

30 Međunarodni roaming je usluga koju nude mobilni operatori uz pomoć koje možete koristiti vaš telefon u inozemstvu. Operator ima sporazume o roamingu sa stranim operatorima, što korisniku pruža mogućnost korištenja mreža tih operatora ostvarivanjem odlaznih i dolaznih poziva, slanja i primanja SMS-poruka, kao i neke druge mobilne usluge (primjerice pristup glasovnoj pošti i nadoplata računa na prepaid telefonima) na isti način kao i kod domicilnih operatora. Raspoložive usluge i troškovi korištenja razlikuju se od operatora do operatora, ovisno o njihovim međusobnim ugovorima. Hrvatska agencija za poštu i elektroničke komunikacije, http://www.hakom.hr/default.aspx?id=343, 25. 1. 2011. 
Cijene roaming-usluge definirane su po minuti razgovora za odlazne pozive unutar strane države i iz strane države prema državama u Europi i svijetu, a na dolazne pozive se plaća naknada za uspostavu poziva. Preslušavanje poruka na telefonskoj sekretarici i mijenjanje postavki naplaćuje se kao odlazni poziv. Cijene odlaznih SMS i MMS-poruka u roamingu posebno su definirane. Dolazne SMS i MMS-poruke su besplatne.

Provjera e-mailova, pristup internoj mreži vlastite tvrtke i zabavnim sadržajima na mobilnom portalu ili surfanje internetom moguće je bez ikakvih ograničenja. Pri korištenju podatkovnih usluga ne obračunava se vrijeme provedeno na mreži već samo količina prenesenih podataka. Cijena ne ovisi o tehnologiji prijenosa (GPRS, EDGE, UMTS ili HSDPA) koja se koristi. Obračunska jedinica je $10 \mathrm{kB}$. Cijene su izražene u kunama/100 KB, cijene mjesečnih paketa za određenu količinu podataka i posebno su definirane cijene prijenosa dodatno prenesenih podataka ili cijene dnevnih paketa za određenu količinu podataka i cijene prijenosa dodatno prenesenih podataka.

Satelitska telefonija pruža globalnu pokrivenost, komunikacija neće biti prekinuta čak ni ako se korisnik nalazi na mjestu na kojem nema GSMsignala, u Hrvatskoj ili u inozemstvu, a cijena usluge je u nekim slučajevima i niža od roaming-usluge.

\subsection{Usluge s posebnom tarifom}

Prema odredbama Zakona o izmjenama i dopunama zakona o elektroničkim komunikacijama, ${ }^{31}$ usluge s posebnom tarifom jesu usluge koje se pružaju putem javnih komunikacijskih mreža i usluga uz uporabu posebnih brojeva, u svrhu ostvarivanja unaprijed određenih sadržaja ili/i usluga u okviru tog sadržaja izvan opsega javnih komunikacija.

\section{POREDBENO PRAVO}

Kazneni zakoni zapadnoeuropskih država u pravilu ne propisuju termin pokretna stvar, ${ }^{32}$ ali gotovo sve tranzicijske države Jugoistočne Europe, nastale raspadom ex federacija, uključujući i posttranzicijsku Republiku Sloveniju, u svojim kaznenim zakonima definiraju pojam pokretna stvar.

31 Članka 2., stavka 1., točke 73. Zakona o izmjenama i dopunama zakona o elektroničkim komunikacijama, NN 90/11.

32 Švicarski kazneni zakon u članku 110., stavak 10. propisuje da se u odredbama koje se odnose na termin ,imovina“ primjenjuje i na životinje. 
Kazneni zakoni Republike Slovenije i Bivše Jugoslavenske Republike Makedonije pojam pokretna stvar definiraju otvoreno kao prijenos glasa odnosno zvuka, slike i teksta na daljinu. Definicija nije određena tehnologijom prijenosa i primjenjiva je na sve današnje tehnologije komunikacije na daljinu.

Slovenski Kazenski zakonik (KZ-1) ${ }^{33}$ u odredbama članka 99., stavka 6. kao pokretnu stvar definira i označava bilo koji oblik energije proizvedene ili skupljene za potrebe rasvjete, grijanja, zračenja, vožnje, kretanja ili prijenosa glasa, slike ili teksta na udaljenostima. Nema kaznenog djela ako je protupravnim postupanjem prouzročena neznatna materijalna šteta ili pribavljena neznatna imovinska korist. ${ }^{34}$

Krivičen zakonik Bivše Jugoslavenske Republike Makedonije ${ }^{35} \mathrm{u}$ odredbama članka 122., stavka 17. pokretnu stvar definira kao i svaku proizvedenu ili sakupljenu energiju davanja svjetlosti, topline ili kretanja kao i telefonski impuls i druga sredstva za prijenos glasa, slike ili teksta na udaljenost ili računalnu uslugu.

Kazneni zakon Federacije Bosne i Hercegovine ${ }^{36}$ u odredbama članka 2., stavka 29. definiciju telefonskih impulsa kao pokretne stvari proširuje i na druge impulse. Prema Kaznenom zakonu Federacije Bosne i Hercegovine pokretnina je i svaka proizvedena ili skupljena energija za davanje svjetlosti, topline ili kretanja, te telefonski i drugi impulsi.

Krivični zakonici Republike Srpske, Republike Srbije i Republike Crne Gore kao pokretne stvari definiraju i računalne podatke i računalne programe. U Krivičnom zakoniku Republike Srbije ${ }^{37}$ i Krivičnom zakoniku Republike Crne Gore $^{38}$ pokretna stvar definirana je kao svaka proizvedena ili sakupljena energija za davanje svjetlosti, topline ili kretanja, telefonski impuls, kao i računarski podatak i računarski program.

33 Kazenski zakonik (KZ-1), Uradni list RS, št. 50/12 - uradno prečiščeno besedilo in 54/15.

${ }^{34}$ Za premično stvar po tem zakoniku se šteje tudi vsaka pridobljena ali zbrana energija za svetlobo, toploto, obsevanje, pogon, premikanje ali prenos glasu, slike ali besedila na daljavo. Protipravna ravnanja s stvarmi po tej določbi ali z nepremičnim premoženjem ali deli tega premoženja se ne štejejo za kazniva dejanja, če je z njimi nastala neznatna premoženjska škoda.

${ }_{35}$ Krivičen zakonik Bivše Jugoslavenske Republike Makedonije, Službeni vesnik na Republika Makedonija broj: 80/99, 4/02 , 43/03,19/04, 81/05, 60/06, 73/06, $7 / 08$, 139/08 , 114/09 51/11, 135/11, $185 / 2011,142 / 2012,166 / 2012,55 / 2013$.

36 Kazneni zakon Federacije Bosne i Hercegovine Sl. novine FBiH 36/03, 37/03, 21/04, 69/04, 18/05, 42/10 i 42/11.

37 Krivični zakonik Republike Srbije, Sl. glasnik RS, br. 85/2005, 88/2005 - ispr., 107/2005 - ispr., 72/2009 i 111/2009, 121/2012, 104/2013 i 108/2014. u odredbama članka 112. stavka 16.

${ }_{38}$ Krivični zakonik Republike Crne Gore, Službeni list Republike Crne Gore, „Sl. list RCG“, br. 70/2003, 13/2004 - ispr. i 47/2006 i „Sl. list CG“, br. 40/2008, 25/2010, 32/2011, 64/2011 - dr. zakon, 40/2013, 56/2013 - ispr., 14/2015, 42/2015 i 58/2015 - dr. zakon. 
Krivični zakon Republike Srpske ${ }^{39}$ u odredbama članka 112., stavka 16. pokretnom stvari smatra i svaku proizvedenu ili sakupljenu energiju za davanje svjetlosti, topline ili kretanja, telefonski impuls, kao i računarski podatak i računarski program.

Prema komparativnoj analizi, svi citirani zakoni na određen način uvažavaju razvoj tehnologije komunikacije na daljinu. Odredbe slovenskog i makedonskog kaznenog zakona u potpunosti udvoljavaju suvremenim računalno-komunikacijskim tehnologijama kao i njihovu predvidivom razvoju.

\section{SUDSKA PRAKSA}

Iz sudske prakse proizlazi da sudovi u presudama na nedostatak odgovarajuce definicije pokretne stvari jednostavno izbjegavaju definirati usluge s dodanom vrijednosti kao pokretnu stvar i jednostavno je uzimaju kao pokretnu stvar.

\subsection{Presuda općinskog suda u Bjelovaru}

Pravomoćnom presudom Općinskog suda u Bjelovaru broj: K-216/10-7 od 2. ožujka 2011. godine okrivljenik je proglašen krivim jer se u vremenskom razdoblju od 14. ožujka 2010. godine do 10. travnja 2010. godine u Bjelovaru, u Franjevačkoj ulici 8 , u namjeri da se okoristi, u više navrata, uz pomoć stolice koju je dovezao svojim osobnim automobilom, penjao na krov kioska - prodavaonice mješovite robe u vlasništvu trgovačkog obrta „Renata“ - skinuo izolaciju s kabela telefonskog priključka navedenog trgovačkog obrta korisničkog broja 043241481 i s tvz. „krokodil-stezaljkama“ telefona marke „Panasonic“ koji je sa sobom nosio, bez znanja i odobrenja vlasnika, spajao na navedeni telefonski priključak i ostvarivao pozive s navedenog korisničkog broja na broj 064614614 davatelja usluga s dodanom vrijednošću „Optimatelekoma“ oštetivši time trgovački obrt „Renata“ za ukupan iznos od 1175,32 kuna. Dakle, svladavanjem većih prepreka, da dođe do stvari iz drugih zatvorenih prostora tuđe pokretne stvari oduzeo je drugome s ciljem da ih protupravno prisvoji, čime je počinio kazneno djelo protiv imovine - teškom krađom, opisano u članku 217., stavak 1., t. 1. u svezi sa člankom 216., st. 1. KZ-a, a kažnjivo po članku 217., st. 1. istoga zakona. Iz presude nije moguće zaključiti je li sud zaključak o „obijanju, provaljivanju ili drugim savladavanjem većih prepreka“ izveo iz okolnosti da se počinitelj uz pomoć stolice penjao na krov kioska (krov $67 / 13$.

39 Krivični zakon Republike Srpske, Sl. glasnik RS, br. 49/03, 108/04, 37/06, 70/06, 73/10, 1/12, 
kioska nije zatvoreni prostor) ili se zaključak o „provaljivanju u zatvoreni prostor“ odnosi na neovlašteno priključivanje na telefonski priključak..$^{40}$

$\mathrm{U}$ presudi sud ne definira usluge s dodanom vrijednosti kao pokretnu stvar, stoga nedostaje bitni element kaznenog djela krađe odnosno kaznenog djela teške krađe, oduzimanje tuđe pokretne stvari. Podvođenje usluga s dodanom vrijednosti pod zakonski izraz telefonski impuls predstavljalo bi, da je Sud usluge s dodanom vrijednosti podveo pod zakonski izraz telefonski impuls, ekstenzivno tumačenje pojma telefonski impuls. Popunjavanje primarnih pravnih praznina zbog potrebe kažnjavanja povrede pravnoga dobra koja nije zakonom propisana kao kazneno djelo, predstavlja zabranjenu zakonsku analogiju na štetu počinitelja. ${ }^{41}$

\subsection{Presuda općinskog suda u Karlovcu}

Pravomoćnom presudom Općinskog suda u Karlovcu broj: 15 K -205/12-10 od 8. kolovoza 2012. godine okrivljenik je proglašen krivim što je u vremenskom razdoblju od 1. listopada 2011. godine do 10. prosinca 2011., u Karlovcu putem svog stolnog računala, bez serijskog broja, te prijenosnog računala marke Asus, model K73S, serijskog broja B6NOAS344467247 i WLAN antene, usprkos mjerama zaštite i bez odobrenja vlasnice T. K., pristupio njezinu ADSL-modemu te trošio internetski promet, počinivši time T. K. materijalnu štetu u novčanom iznosu od 2237,73 kuna. Dakle, unatoč zaštitnim mjerama, neovlašteno je pristupio računalnom sustavu, čime je počinio kazneno djelo protiv imovine - povredom tajnosti, cjelovitosti i dostupnosti računalnih podataka, programa ili sustava, označeno u čl. 233, st. 1. KZ-a. Temeljem čl. 158., st. 1. i 2. oštećenoj T. K. dosuđuje se imovinskopravni zahtjev u iznosu od 2237,73 kuna koji je okrivljenik dužan platiti u roku od 15 dana po pravomoćnosti presude pod prijetnjom ovrhe.

U navedenim presudama niti jedan sud ne definira usluge s dodanom vrijednosti i prijenosa računalnih podataka kao pokretnu stvar. U presudi općinskog suda u

40 Podizanje novca iz bankomata pomoću ukradene kartice i tajnog osobnog broja PIN kvalificirano je kao kazneno djelo teške krađe iz članka 217., stavak 1., točka 1. Kaznenog zakona. Naime, drugostupanjski sud je zaključio da su okrivljenici, djelujući u sprezi, počinili kazneno djelo teške krađe iz članka 217., stavak 1., točka 1. u svezi s člankom 216., stavak 1. Kaznenog zakona. Okrivljenici su uporabom kartice tekućeg računa s pribavljenim PIN-brojem za navedenu karticu provalili u zatvoreni prostor, $\mathrm{tj}$. bankomat, uzevši pri tomu novac s ciljem da ga protupravno prisvoje. Zupanijski sud u Bjelovaru, kao drugostupanjski sud, konstatira da je neovlašteno ulaženje tuđom karticom u bankomat ,provaljivanje u zatvoreni prostor", a time i obilježje teške krađe. Presude Županijskog suda u Bjelovaru Kž-397/02 od 7. 11. 2002. godine i Kž-71/05 od 17. 3. 2005. godine.

${ }^{41}$ Kako se načelo zakonitosti, pa prema tome i zabrana analogije, prema izričitoj ustavnoj i zakonskoj normi odnosi samo na propisivanje kaznenih djela i kaznenopravnih sankcija (analogija na štetu počinitelja ili analogia in malam partem), prevladava stajalište da je načelno dopuštena analogija u korist počinitelja (analogia in bonum pratem). Novoselec, P., Opći dio kaznenog prava, drugo izmijenjeno izdanje, Pravni fakultet u Zagrebu, Zagreb, 2007. godine, str. 76-77. 
Bjelovaru, nedostaje bitni element kaznenog djela krađe oduzimanje tuđe pokretne stvari. Podvođenje usluga s dodanom vrijednosti pod zakonski izraz telefonski impuls predstavljalo bi, da je Sud usluge s dodanom vrijednosti podveo pod zakonski izraz telefonski impuls, ekstenzivno tumačenje pojma telefonski impuls.

Općinski sud u Karlovcu neovlašteno korištenje internetskog prometa ne definira niti kao krađu. Naime, odredbe članka 233., stavka 1. propisuju kazneno djelo neovlaštenog pristupa računalnom sustavu, a odredbom članka 233., stavka 5. propisan je kvalificirani oblik kaznenog djela neovlaštenog pristupa ako je počinjenjem osnovnog kaznenog djela, između ostalog, počinjena znatna šteta i Sud se u presudi niti ne poziva na navedenu odredbu.

Stvarna potreba sankcioniranja neovlaštenog korištenja prijenosa računalnih podataka, zvuka i slike na daljinu nedvojbeno postoji, međutim prijenos računalnih podataka, zvuka i slike na daljinu u Kaznenom zakonu nisu izričitim odredbama definirani kao pokretna stvar.

\section{NAPLATA KOMUNIKACIJSKIH USLUGA}

Komunikacijska usluga u pravilu se pruža uz naknadu, a sastoji se u cijelosti ili većim dijelom od prijenosa digitalnog signala u komunikacijskim mrežama. Vrste komunikacijskih usluga, kao i načini naplate komunikacijskih usluga, mijenjaju se razvojem informacijsko-komunikacijske tehnologije.

Telefonski impulsi kao pokretna stvar, zadovoljavali su potrebe kaznenopravne zaštite javne telekomunikacijske govorne usluge devedesetih godina prošlog stoljeća. Uvedena je i telefonska kartica kao surogat gotovog novca za plaćanje javne telekomunikacijske govorne usluge. Telefonska kartica je telekomunikacijska vrijednosnica ${ }^{42}$ na kojoj je otisnut nominalni broj impulsa koji se automatski smanjuje uporabom telefonske kartice, a na telefonskom aparatu s automatskom naplatom moguće je očitati preostali raspoloživi broj impulsa. VSRH je svojim presudama i rješenjima, interpretacijom propisa nedvojbeno potvrdio da su telefonske kartice vrijednosnice. ${ }^{43}$ Uporaba krivotvorene telefonske kartice - beskonačne

42 Telekomunikacijska vrijednosnica je telefonska kartica, što služi kao sredstvo plaćanja telefonskih usluga na telefonskim aparatima s automatskom naplatom, a na kojoj je unaprijed otisnuta ili na drugi pogadan način označena vrijednost telekomunikacijske usluge. Članak 5., stavak 2. Pravilnika o poštanskim markama i vrijednosnicama, HPT - Hrvatska pošta i telekomunikacije, broj: Z-1-6105/95 od 16. kolovoza 1995.

${ }^{43}$ Pritom, iako državni odvjetnik nije na glavnoj raspravi izmijenio, ni proširio optužnicu, prvostupanjski sud se upustio u izmjenu činjeničnog opisa djela na način da je upravo u činjeničnom opisu djela označio, bitno različito od državnog odvjetnika, da je modificirana telefonska kartica izrađena protivno Pravilniku o poštanskim markama i vrijednosnicama, koje izdaje HPT, te suprotna čl. 10. Svjetske poštanske konvencije, i čl. 30., st. 2. Zakona o pošti, s naznakom vremena kada je od optuženika navedena telefonska kartica oduzeta. VSRH, Presuda i rješenje broj: I Kž 968/03-6. od 30 08. 2006 
Dr. sc. Dražen Škrtić: Prijenos računalnih podataka - pokretna stvar u kaznenom zakonu Zbornik radova Pravnog fakulteta u Splitu, god. 53, 3/2016., str. 855.-872.

telefonske kartice ${ }^{44}$ omogućavala je korisniku neograničeno korištenje govorne telekomunikacijske usluge jer se nominalni iznos impulsa na kartici automatski obnavljao. Iz presuda VSRH-a nije razvidno je li u kaznenom postupku utvrđivan novčani iznos za koji su okrivljenici uporabom krivotvorene telefonske kartice oštetili davatelja govorne telekomunikacijske usluge odnosno iznos pribavljene protupravne imovinske koristi.

Novim pravilnicima o obavljanju djelatnosti javnih komunikacijskih usluga naplata usluga vrši se u pravilu po ispostavljenom računu (postpaid) i posebnim vrstama plaćanja unaprijed (prepaid) bonom u pokretnoj i telefonskom karticom u nepokretnoj elektroničkoj komunikacijskoj mreži, a za usluge s dodanom vrijednosti - plaćanje unaprijed, ${ }^{45}$ sukcesivno plaćanje ${ }^{46}$ i plaćanje proizvoda. ${ }^{47}$

Prema aktualnim pravilnicima, telefonska kartica kao vrijednosni znak ima pravno svojstvo vrijednosnih znakova kao surogata za plaćanje gotovim novcem, ima određenu nominalnu vrijednost izraženu u kunama, ${ }^{48}$ a koristi se za unaprijed plaćene usluge u nepokretnoj elektroničkoj komunikacijskoj mreži. Novčani iznos

Tijekom postupka, provedenim vještačenjji čiji nalka optuženi niti ne osporava, nedvojbeno je utvrđeo, da je telefonska kartica, koja je od opt. Š. Oduzeta, krivotvorina. Optuženi Š po svom obrazovanju tehničara za telekomunikacije koji je radio u to vrijeme u TKC Z., posve sigurno je zno, da se radi o krivotvorenoj telefonskoj kartii, koa se trošenjem prazni i vrijednosti je 200 impulsa. Ona je nedvojbeno znak za vrijednost, a optuženi ju je pribaviosa jedinom namjerom da je uporabi kao pravu. VSRH, Presuda i rješenje broj: I Kž 682/01-8 od 30 01. 2002.

44 VSRH, Rješenje: Broj: II-4 Kr-280/00-3, 31. 8. 2000.

45 Prepaid: kod ove usluge potrebno je unaprijed platiti navedeni novčani iznos što omogućuje korisniku uporabu usluge na odredbeno razdoblje (npr. glavne teme dnevnih novina na razdoblje od mjesec dana), Članak 13., stavak 1., točka 1. Dodatak 5. Pravila postupanja za operatore usluga s dodanom vrijednosti Pravilnika o načinima i uvjetima obavljanja djelatnosti elektroničkih komunikacijskih mreža i usluga, NN 154/2011.

46 Pay as you go: predstavlja uslugu kod koje zahtjev za aktivacijom usluge (npr. putem SMS-a) dovodi do serije uporabe i plaćanja aktiviranih usluga (npr. kada isporuka usluge dnevnih najvažnijih vijesti bude plaćena za jedan dan automatski dovodi do usluge davanja dnevnih najvažnijih vijesti idućeg dana te se takav sustav naplate i davanja usluge provodi sve do trenutka dok korisnik ne prekine uporabu usluge). Članak 13., stavak 1., točka 2. Pravilnika o načinima i uvjetima obavljanja djelatnosti elektroničkih komunikacijskih mreža i usluga, NN 154/2011.

47 Na uslugu „Plati proizvod“ (Pay-for-product) primjenjuju se odredbe zakona i podzakonskih propisa u Republici Hrvatskoj kojima se uređuju ugovorne obveze za ugovore sklopljene na daljinu. Članak 16. Pravilnika o načinima i uvjetima obavljanja djelatnosti elektroničkih komunikacijskih mreža i usluga, NN 154/2011.

48 Zakonom o pošti, oba znaka, i to poštanska marka kao poštanski vrijednosni znak, te telefonska kartica kao telekomunikacijski vrijednosni znak, imaju pravno svojstvo vrijednosnih znakova kao surogata za plaćanje gotovim novcem, jednako kao i Pravilnikom o poštanskim markama i ostalim vrijednosnicama u koje ulazi i telefonska kartica. Kazneno djelo krivotvorenja znakova za vrijednost iz čl. 276., st. 1. KZ-a, ima zaštitni objekt sigurnost platnog prometa i poslovanja i ulazi u Glavu XXI. Kaznenog zakona, koje se odnosi na kaznena djela protiv sigurnosti platnog prometa i poslovanja, dok kazneno djelo krivotvorenja privatne isprave ulazi u kaznena djela protiv vjerodostojnosti isprava (Glava XXIII. Kaznenog zakona), kojima je objekt zaštite čistoća, vjerodostojnost i nepovredivost isprava, iz čega je očito da postoji bitna razlika između navedenih kaznenih djela glede njihovih objekata zaštite, zakonskih obilježja, kao i visine zapriječenih kazni zatvora za odnosna djela. Presuda i Rješenja VSRH broj: I Kž 968/03-6 od 30. kolovoza 2006. godine. 
naznačen u nominalnoj vrijednosti telefonske kartice ne može se nadoplaćivati, a koristi se isključivo za plaćanje javno dostupnih telefonskih usluga. ${ }^{49}$

U pokretnoj elektroničkoj komunikacijskoj mreži za unaprijed plaćene usluge davatelj usluga izdaje bon (otisnut na papiru ili u elektroničkom obliku) kao korisnički račun s novčanim iznosom u svrhu korištenja javnih komunikacijskih usluga $^{50}$ koji se može nadopunjavati novim novčanim iznosima nakon prvobitne kupnje ${ }^{51}$ a pored plaćanja javnih komunikacijskih usluga novčani iznos moguće je koristiti i za plaćanje drugih usluga (naknade za parkiranje).

\section{ZLOUPORABA KOMUNIKACIJSKE TEHNOLOGIJE}

Suvremena informacijskai komunikacijska tehnologija nije imuna na zlouporabe. Osnovnim oblicima neovlaštenog pristupa i korištenja komunikacijske tehnologije, uporabe telefona u pokretnim i nepokretnim mrežama radi komunikacije na daljinu treba dodati i prijenos kratkih tekstualnih poruka SMS, prijenos slike i zvuka MMS i prijenos računalnih podataka.

Iako se za obračun javnih komunikacijskih usluga, prema citiranim propisima, ne koriste impulsi već iznosi izraženi u novčanim jedinicama po vremenskom intervalu, termin „krađa impulsa“ je u širokoj kolokvijalnoj uporabi. Neke od zlouporaba suvremene komunikacijske tehnologije bitno se ne razlikuju od zlouporaba prijenosa govora na daljinu, jednostavnim neovlaštenim priključivanjem na telekomunikacijske vodove korisnika..$^{52}$ Jednostavno neovlašteno priključivanje na telefonske priključke radi korištenja javne komunikacijske usluge, prošireno je i na izravno pribavljanje značajne imovinske koristi, a korišteno je za račun obrta čiji je vlasnik prethodno zaključio ugovor s HT-om d.d. o pružanju usluga u

49 Usluga koja je dostupna javnosti za izravno ili neizravno slanje i primanje nacionalnih poziva ili nacionalnih i međunarodnih poziva biranjem brojeva iz nacionalnog ili međunarodnog plana numeriranja, Članak 2., stavak 1., točka 22. Zakona o izmjenama i dopunama zakona elektroničkim komunikacijama, NN 90/11.

50 Elektronička komunikacijska usluga koja je javno dostupna na tržišnoj osnovi, Članak 2., stavak 1., točka 20. Zakona o izmjenama i dopunama zakona o elektroničkim komunikacijama, NN 90/11.

51 Članak 29., stavak 1. Pravilnika o načinima i uvjetima obavljanja djelatnosti elektroničkih komunikacijskih mreža i usluga, NN 154/2011.

52 POPEO SE NA KROV I KRAO IMPULSE. Kradljivac impulsa se telefonom s kablom, na čijem su kraju krokodil-stezaljke, spojio na krovni kabel telefonskog priključka kioska-trgovine Renata u Franjevačkoj ulici u Bjelovaru te potom s krova kioska, na račun vlasnice trgovine, danima nazivao brojeve s dodatnom vrijednosti. Kriminalističkim istraživanjem utvrđeno je da je u posljednjih mjesec dana, nakon radnog vremena trgovine, nazivao brojeve usluga s dodatnom vrijednošću. Osim u ožujku, s krova kioska telefonirao je i ovoga mjeseca te je vlasnicu trgovine u kratko vrijeme oštetio za oko 1.200 kuna, a da nije bilo savjesnih građana, taj bi iznos zasigurno bio i mnogo veći. T portal, 14. 4.2010., http:// www.tportal.hr/vijesti/crnakronika/63629/Popeo-se-na-krov-i-krao-impulse.html, 28. 6. 2012. 
Dr. sc. Dražen Škrtić: Prijenos računalnih podataka - pokretna stvar u kaznenom zakonu Zbornik radova Pravnog fakulteta u Splitu, god. 53, 3/2016., str. 855.-872.

tarifnoj mreži 060xxxxxx radi ostvarivanja prihoda po uspostavljenom telefonskom kontaktu i dužini trajanja telefonskih kontakata. ${ }^{53}$

Razvoj mobilne komunikacijske mreže, korištenje roaminga omogućuje uporabu sofisticirane opreme radi pribavljanja znatno većih iznosa imovinske koristi, koja se ne može podvesti pod krađu impulsa, odnosno kazneno djelo teške krađe. Počinitelj je pomoću osobnog računala i posebnog softvera iščitao tzv. SIM-ključeve (identifikacijske oznake) sa svoje SIM-kartice i SIM-kartica još tri osobe. Nakon toga je pomoću posebnog uređaja sastavio duplikate ovih kartica te ih dao na uporabu nepoznatim osobama koje su ih koristile telefoniranjem u tzv. roaming usluzi u Ukrajini i Kazahstanu. Takvim korištenjem tvrtki „T-Mobile Hrvatska“ d.o.o. pričinjena je šteta u iznosu od 780.459,23 kune ${ }^{54}$ Kazneno djelo je kvalificirano kao računalno krivotvorenje iz članka 223.a, stavak 1. i 2. Kaznenog zakona. Odredbom stavka 2. propisuje se kvalificirani oblik kaznenog djela ako je kazneno djelo počinjeno na štetu trgovačkog društva od posebnog javnog interesa ili je prouzročena znatna šteta. Prema odredbama KZ/11, za kazneno djelo računalnog krivotvorenja u članku 270. nije propisan kvalificirani oblik kaznenog djela kojim je prouzročena znatna šteta, ${ }^{55}$ a člankom 273. propisan je kvalificirani oblik kaznenog djela računalnog krivotvorenja ako je kazneno djelo počinjeno u odnosu na računalne podatke trgovačkog društva od posebnog javnog interesa. Ukoliko uzmemo da je svaki davatelj usluga elektroničkih komunikacija trgovačko društvo od posebnog javnog interesa, navedeno ponašanje počinitelja bilo bi prema citiranim odredbama KZ/97 i KZ/11 kažnjivo, a pri tom je visina prouzročene

53 Općinsko državno odvjetništvo podiglo je pred Općinskim sudom u Zagrebu optužni prijedlog protiv hrvatske državljanke G. P. (1965.) i hrvatskih državljana T. S. (1961.), M. T. R. (1974.) i I. R. (1976.) zbog ukupno 15 kaznenih djela teških krađa iz čl. 217. Kaznenog zakona (27. 6. 2006.). G. P. se stavlja na teret četrnaest kaznenih djela teških krađa iz čl. $217 \mathrm{KZ}$-a koja je počinila zajedno sa M. T. R. i I. R. tijekom ožujka i travnja 2006. godine na način da su M. T. R. i I. R., zajedno i po prethodnom dogovoru s G. P., u stubištima većeg broja stambenih zgrada na području Zagreba i Velike Gorice, obijali telefonske ormariće i priključivali se na telefonske priključke stanara - pretplatnika fiksne telefonske mreže HT-a d.d. Na taj način su uspostavljani telefonski kontakti s telefonskim brojem 060xxxxxx, dodijeljen spomenutom obrtu, na koji način su otuđili telefonske impulse u ukupnoj vrijednosti od 116.523,24 kune, a sve na štetu stanara, pretplatnika tih stambenih zgrada, i HT-a d.d. http://www.dorh.hr/ Default.aspx?art=5071\&sec=665, 28. 6. 2012.

54 Općinsko državno odvjetništvo u Đakovu podnijelo je Općinskom sudom u Đakovu optužni prijedlog protiv hrvatskog državljanina T.-I. J. (1974.) zbog kaznenih djela računalnog krivotvorenja iz članka 223.a, stavak 1.2. Kaznenog zakona, povrede prava industrijskog vlasništva i neovlaštene uporabe tuđe tvrtke iz članka 285., stavak 1. i 2. KZ-a i zlouporabe opojnih droga iz članka 173., stavak 1. KZ-a (2. 10. 2007.). Optužnim prijedlogom mu se stavlja na teret da je tijekom 2005. i 2006. godine u Breznici Đakovačkoj, pomoću osobnog računala i posebnog softvera iščitao tzv. SIM-ključeve (identifikacijske oznake) sa svoje SIM-kartice i SIM-kartica još tri osobe. Nakon toga je pomoću posebnog uređaja sastavio duplikate ovih kartica te ih dao na uporabu nepoznatim osobama koje su ih koristile telefoniranjem u tzv. roaming usluzi u Ukrajini i Kazahstanu. Takvim korištenjem tvrtki „T-Mobile Hrvatska“ d.o.o. pričinjena je šteta u iznosu od 780.459,23 kune. http://www.dorh.hr/Default.aspx?art=6013\&sec=555 21.06. 2010 .

55 U ovom dijelu, Novi kazneni zakon kazneno djelo protiv vjerodostojnosti računalnih podataka koji imaju vrijednost za pravne odnose propisuje kao i ostala kaznena djela protiv vjerodostojnosti isprava, bez odredbi o materijalnoj šteti. 
štete irelevantna. Međutim, po kriteriju visine materijalne štete, prema Novom kaznenom zakonu, ponašanje počinitelja ne bi bilo kažnjivo. Državno odvjetništvo je primijenilo jedino moguću kvalifikaciju kaznenog djela jer se telefoniranje ne može podvesti pod potrošnju ili krađu impulsa odnosno tešku krađu zbog visine materijalne štete iz članka 217., stavak 2., točka 1. KZ/97.

Tehnike zlouporabe koriste se u cilju korištenja informacijske i komunikacijske tehnologije na način koji će određenoj osobi omogućiti korištenje usluge komunikacije i prijenosa podataka na štetu legitimnog korisnika ili davatelja usluga. Tehničke mogućnosti za zlouporabe kao i za legitimno korištenje komunikacijske tehnologije vrlo su razvijene. Prijenos podataka koji uključuje prijenos računalnih podataka $i$ audiovizualnih sadržaja $s$ interneta $i$ njihovo pohranjivanje na medije za pohranu računalnih podataka jedan je od raširenijih oblika neovlaštenog korištenja informacijske i komunikacijske tehnologije.

\section{ZAKLJUČAK}

Prijenos govora, kratke tekstualne poruke (SMS), prijenos slike, govora i zvuka porukom (MMS) odnosno prijenos govora, teksta, slike, zvuka i podataka nije vezan za vrstu sredstva za komunikaciju niti za pokretnu ili nepokretnu komunikacijsku mrežu. Tehnološka rješenja suvremenih računala i pametnih mobilnih telefona omogućuju korištenje svih vrsta prijenosa govora, zvuka, teksta, slike i računalnih podataka u pokretnoj ili nepokretnoj elektroničkoj komunikacijskoj mreži, a naplata usluge vrši se prema cijeni korištene usluge.

Definicija telefonskih impulsa u kaznenom zakonu nije se mijenjala tijekom 13 izmjena i dopuna KZ/97 niti je propisana u KZ/11 i njegove dvije izmjene i jednim ispravkom, a s obzirom na tehnološki razvoj informacijske i komunikacijske tehnologije neprimjenjiva je. Novi oblici i sredstva za komunikaciju na daljinu i prijenos govora, slike, zvuka i računalnih podataka, kao i zlouporaba informacijske i komunikacijske tehnologije $s$ namjerom pribavljanja protupravne imovinske koristi neovlaštenim korištenjem javno dostupnih telekomunikacijskih usluga, zahtijevaju adekvatnu kaznenopravnu reakciju i dopune definicije pokretne stvari koja bi obuhvaćala i prijenos govora, slike, zvuka i računalnih podataka kao pokretne stvari. 


\section{TRANSMISSION OF COMPUTER DATA- MOVEABLE MATTER IN CRIMINAL LAW}

Criminal law response to the development of information and communication technology and misuse of public communications service for a long period of time does not follow contemporary models of collection of digital electronic communications services, value added services, transfer pictures, sound, text and computer data in units adapted to the type of service. The legislator did not follow the trends of the progressive development of information and communication technologies, and adapt the definition of movable objects. Transfer images, sound and text electronic data remotely according to the provisions of the Criminal Code is not movable objects, nor the extensive interpretation of the concept phone impulse does not fall within the definition of movable objects. Unauthorized use of modern forms of communication and data transfer can not be defined as a criminal act of theft and aggravated theft because that would be contrary to the principle of legality. Court decisions in proceedings initiated due to unauthorized use of value added services and transmission of computer data not define these services as movable objects. On the basis of the general indications of modern communication services, comparative legislation and case-law that the need to be in the Criminal Code transfer images, sounds, text and computer data remotely defined as movable object.

Key words: Criminal code, telephone impulses, movable object, transfer of computer data 